\title{
Peripheral Myelin Maintenance Is a Dynamic Process Requiring Constant Krox20 Expression
}

\author{
Laurence Decker, ${ }^{1}$ Carole Desmarquet-Trin-Dinh, ${ }^{1}$ Emmanuel Taillebourg, ${ }^{1}$ Julien Ghislain, ${ }^{1}$ Jean-Michel Vallat, ${ }^{2}$ and \\ Patrick Charnay ${ }^{1}$ \\ ${ }^{1}$ Institut National de la Santé et de la Recherche Médicale, U784, Ecole Normale Supérieure, 75230 Paris Cedex 05, France, and ${ }^{2}$ Laboratoire de Neurologie, \\ Centre Hospitalier Universitaire Dupuytren, 87042 Limoges, France
}

\begin{abstract}
Onset of myelination in Schwann cells is governed by several transcription factors, including Krox20/Egr2, and mutations affecting Krox20 result in various human hereditary peripheral neuropathies, including congenital hypomyelinating neuropathy (CHN) and Charcot-Marie-Tooth disease (CMT). Similar molecular information is not available on the process of myelin maintenance. We have generated conditional Krox20 mutations in the mouse that allowed us to develop models for CHN and CMT. In the latter case, specific inactivation of Krox20 in adult Schwann cells results in severe demyelination, involving rapid Schwann cell dedifferentiation and increased proliferation, followed by an attempt to remyelinate and a block at the promyelinating stage. These data establish that Krox 20 is not only required for the onset of myelination but that it is also crucial for the maintenance of the myelinating state. Furthermore, myelin maintenance appears as a very dynamic process in which Krox20 may constitute a molecular switch between Schwann cell myelination and demyelination programs.
\end{abstract}

Key words: peripheral nervous system; Krox20/Egr2/Zif268; myelinopathy; Schwann cell; mouse model; gene

\section{Introduction}

In the vertebrate peripheral nervous system (PNS), Schwann cells are in charge of elaborating the myelin sheath, the specialized membrane structure that allows rapid nerve conduction. Although the molecular mechanisms controlling Schwann cell development are still primarily unknown, progress has been made recently in the identification of key regulators of the onset of myelination. This process is governed by transcription factors including the POU proteins Oct6 (SCIP) and Brn2, the highmobility group protein Sox10, and the zinc finger protein Krox20 (also known as Egr2) associated with its cofactors, the Nab proteins (Topilko et al., 1994; Jaegle et al., 1996; Warner et al., 1998; Le et al., 2005b; Ghislain and Charnay, 2006). Accumulating evidence generated in the mouse suggests that Krox20 plays the role of a master gene in this process: (1) Krox20 is activated in Schwann cells after axonal contact, before myelination (Topilko et al., 1994, 1997; Murphy et al., 1996); (2) Krox20 null or hypomorphic mutations result in a block in the myelination program

\footnotetext{
Received Feb. 17, 2006; revised July 4, 2006; accepted Aug. 3, 2006.

This work was supported by grants to P.C. from the Institut National de la Santé et de la Recherche Médicale, the Ministère de l'Education Nationale de la Recherche et de la Technologie, the Association pour la Recherche sur la Sclérose en Plaque, the Association pour la Recherche sur le Cancer, and the Association Française contre la Myopathie. L.D. was supported by a postdoctoral fellowship from the Fondation pour la Recherche Médicale. We thank Dr Anton Berns for the kind gift of the R26-CreER ${ }^{\top}$ mice. We are grateful to Laurence Richard and Martine Piaser for excellent technical assistance in electron microscopy and to S. Garel, P. Topilko, and A. Baron-Van Evercooren for critical reading of this manuscript.

Correspondence should be addressed to Patrick Charnay, Institut National de la Santé et de la Recherche Médicale, U784, Ecole Normale Supérieure, 46 rue d'Ulm, 75230 Paris Cedex 05, France. E-mail: charnay@wotan.ens.fr.

E. Taillebourg's present address: Commissariat à l'Energie Atomique, Laboratoire de Biochimie et Biophysique des Systèmes Intégrés, 38054 Grenoble, France.

DOI:10.1523/JNEUROSCI.0716-06.2006

Copyright $\odot 2006$ Society for Neuroscience $\quad 0270-6474 / 06 / 269771-09 \$ 15.00 / 0$
}

at the promyelinating stage, with Schwann cells having established a 1:1 ratio with the axons but unable to proceed with the spiralization process (Topilko et al., 1994; Le et al., 2005a); and (3) forced Krox20 expression in Schwann cells results in the activation of genes encoding structural myelin proteins and enzymes involved in lipid synthesis (Nagarajan et al., 2001).

Consistent with the observations performed in the mouse, the crucial role of Krox20 in the control of Schwann cell myelination is supported by the association of various, dominant, or recessive Krox20 mutations with several types of human peripheral neuropathies. These include congenital hypomyelinating neuropathy $(\mathrm{CHN})$, as well as late-onset conditions such as CharcotMarie-Tooth disease (CMT) 1D subtype and Dejerine-Sottas syndrome (DSS) (Warner et al., 1998; Bellone et al., 1999; Timmerman et al., 1999; Pareyson et al., 2000; Boerkoel et al., 2001; Yoshihara et al., 2001).

In contrast to the onset of myelination, very little information is available on the mechanisms controlling the maintenance of the myelin sheath, although the existence of late-onset peripheral myelinopathies underlines the importance of this process and a mutation in the Ndrg1 gene has been shown to result in progressive demyelination in the mouse (Okuda et al., 2004). The permanent expression of Krox20 in myelinating Schwann cells and its downregulation after axonal injury that results in the elimination of the myelin sheath, in a process known as Wallerian degeneration (Zorick et al., 1996; Ghislain et al., 2002), raises the possibility that Krox20 expression might be required for myelin maintenance.

To investigate this issue, we have developed conditional Krox20 mutations based on a floxed allele (Taillebourg et al., 2002) and using different protocols for Cre-mediated excision, 
which allowed us to establish animal models that mimic CHN or CMT. In particular, clinical, immunohistochemical and ultrastructural analyses established that Krox20 inactivation in the adult sciatic nerve leads to rapid demyelination as a result of Schwann cell dedifferentiation. Myelin maintenance is therefore a dynamic process in which Krox20 may act as a reversible molecular switch governing both myelination and demyelination programs.

\section{Materials and Methods}

Generation of mutant mice and genotyping. The Krox $20^{f l o x}$ allele was obtained by Cre-mediated deletion of the neo gene from a Krox $20^{\text {floxneo }}$ allele (Taillebourg et al., 2002). To generate Krox $20^{\text {Cre/flox }}$ mutants, Krox $20^{\text {Crel+ }}$ mice (Voiculescu et al., 2000) were mated with Krox $20^{\text {flox }}$ flox mice. Krox $20^{\text {lacZ/+ }}$, R26-CreER ${ }^{T}$ animals were obtained by crossing Krox $20^{\text {lacZ/+ }}$ mice (Topilko et al., 1994) with R26-CreER ${ }^{T}$ mice (Vooijs et al., 2001). Krox2 $0^{\text {lacz/flox }}, R 26-C r e E R^{T}$ mice were obtained by crossing Krox $20^{\text {lacZ/+ }}, R 26-C_{\text {CreER }}{ }^{T}$ with Krox $20^{f l o x / f l o x}$ animals. Genotyping was performed by PCR on tail DNA using primers specific for Cre (5'-GTCCGGGCTGCCACGACCAA-3' and 5'ACGGAAATCCATCGCTCGACCAGT- $3^{\prime}$ ), the floxed Krox20 allele (5'-GTGTCGCGCGTCAGCATGCGTG-3' and 5'-GGGAGCGAAGCTACTCGGATACGG-3'), and lacZ (5'GTCGTTTTACAACGTCGTGACT- $3^{\prime}$ and $5^{\prime}$ GATGGGCGCATCGTAACCGTGC-3'). Recombinant DNA and animal manipulations were performed according to French and European Union regulations.

Induction and characterization of Cremediated deletion of the Krox20 second exon. For intraperitoneal injection, tamoxifen (TM; Sigma, l'Isle d'Abeau Chesnes, France) was suspended in a sunflower oil/ethanol (10:1) solution at $10 \mathrm{mg} / \mathrm{ml}$. Experimental mice received two $1 \mathrm{mg}$ injections of TM per day for 5 consecutive days, and control animals were treated in the same way with the carrier only. For focal administration into the sciatic nerve, $0.1 \%$ hydroxytamoxifen (OHT; Sigma) was dissolved in a water solution containing $0.9 \% \mathrm{NaCl}$ and $2 \%$ DMSO. Mice were deeply anesthetized, the sciatic nerve was uncovered, and $3 \mu \mathrm{l}$ of the OHT solution was injected using a $10 \mu$ l Hamilton syringe. Control animals received the carrier (DMSO). To characterize the deletion of the floxed Krox20 allele, DNA was extracted from the sciatic nerve and analyzed by PCR using specific primers. Amplifications with primers p3 and p4 of wild-type and Krox $20^{f l o x}$ alleles generate 160 and 195 bp DNA fragments, respectively; primers $\mathrm{p} 2$ and $\mathrm{p} 3$ amplify a $210 \mathrm{bp}$ DNA fragment from the excised Krox $20^{\Delta}$ allele (Taillebourg et al., 2002). Primer sequences are as follows: p2, 5'-AGTTGACAGCCCGAGTCCAGTGG-3'; p3， 5'-GTGTCGCGCGTCAGCATGCGTG-3'; p4, 5'-GGGAGCGAAGCTACTCGGATACGG-3'. The relative intensities of the bands in PCR analyses were quantified using the Image Gauge program (Fujifilm, Tokyo, Japan). a

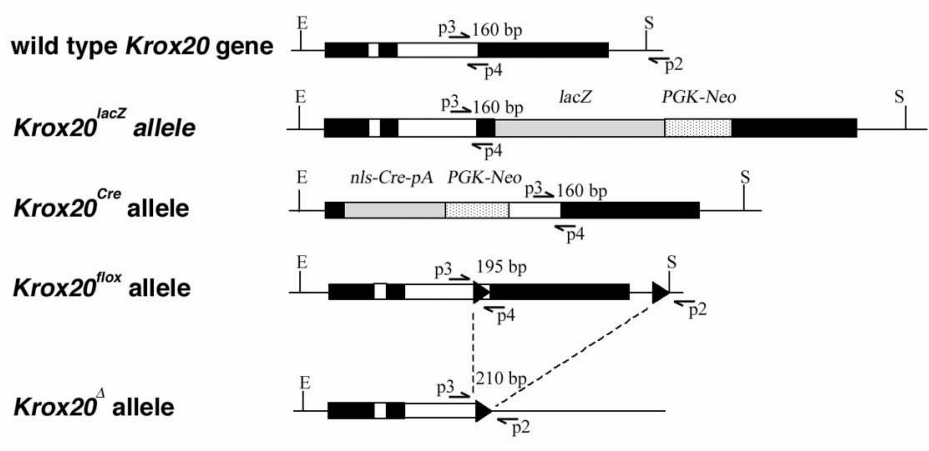

b

C
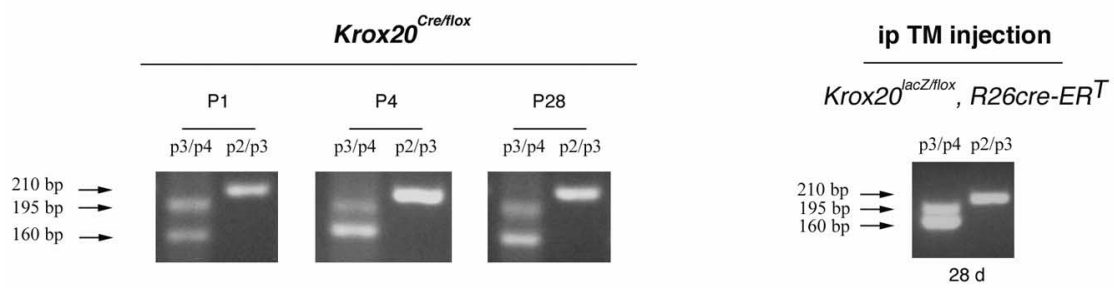

d

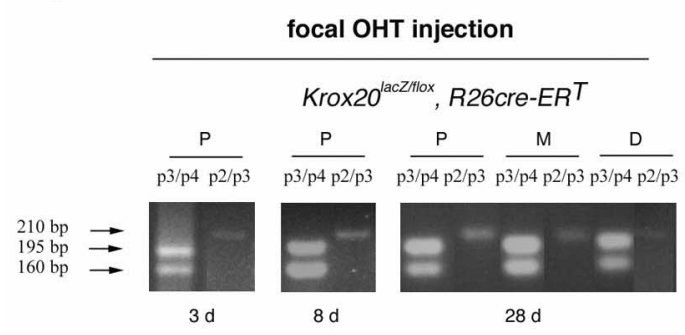

DMSO injection (control)

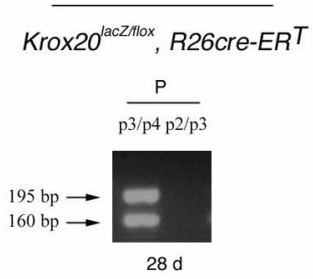

e

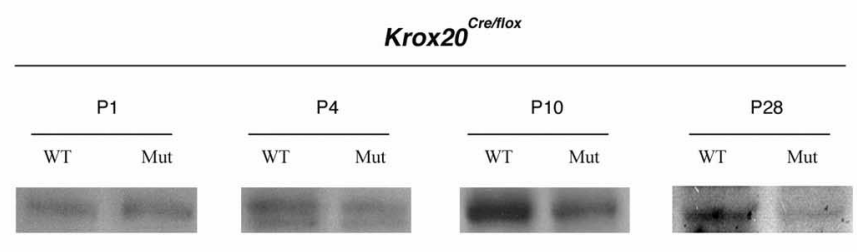

f
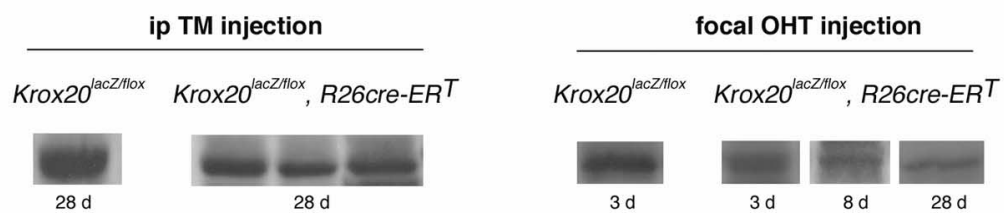

Figure 1. Conditional excision of the floxed Krox20 allele. $\boldsymbol{a}$, Schematic representation of the different Krox20 alleles, including the following: wild-type, $K r o \times 20^{\text {lac }}$, Krox $20^{\text {Cre }}$, floxed $\left(K r o \times 20^{f l o x}\right)$, and deleted $\left(K r o \times 20^{\Delta}\right)$ alleles. loxP sites are indicated by black arrowheads. Arrows indicate the positions of the primers used for PCR amplification, and the sizes of the amplified fragments are shown above the fragments. Primers $\mathrm{p} 3$ and $\mathrm{p} 4$ produce 160 and $195 \mathrm{bp}$ fragments from wild-type and Krox $20^{\text {flox }}$ alleles, respectively; primers p2 and p3 amplify a 210 bp fragment from the Krox $20^{\Delta}$ allele. E, EcoRl; S, Spel. $\boldsymbol{b}-\boldsymbol{d}, \mathrm{PCR}$ analysis of sciatic nerve DNA from P1, P4, and P28 Krox $20^{\text {crefflox }}$ mutants (b), extracted $28 \mathrm{~d}$ after injection from intraperitoneally injected TM (two rounds of 5 injections) (c) or extracted 3, 8, and $28 \mathrm{~d}$ after injection from focally OHT- and DMSO-injected animals with the indicated genotypes $(\boldsymbol{d})$. The excision of the second exon is demonstrated by the appearance of the $210 \mathrm{bp} P$ PCR fragment (deleted allele) and the relative reduction of the $195 \mathrm{bp}$ fragment (Krox20 flox allele) compared with the $160 \mathrm{bp} \mathrm{fragment}$ (lacZ or Cre allele). Note the approximate twofold relative reduction of the floxed allele from P4 in Krox $20^{\text {Crefflox }}$ animals $(\boldsymbol{b})$ and the detection of the deleted allele as early as $3 \mathrm{~d}$ after focal $\mathrm{OHT}$ injection ( $\boldsymbol{d}$ ). The letters above the lanes in $\boldsymbol{d}$ refer to the position of the nerve sample used for DNA extraction with respect to the site of injection: $P$, proximal, 5-mm-long pieces centered on the 
Western blotting analysis. Sciatic nerves were homogenized in lysis buffer (50 mu Tris, pH 7.5, $150 \mathrm{~mm} \mathrm{NaCl,} 5$ mm EDTA, 1\% Triton-X100, $1 \%$ SDS) with brief sonication on ice. Protein levels were quantified using the Bio-Rad (Hercules, CA) protein assay with BSA as a standard. Equal amounts of proteins $(10-50 \mu \mathrm{g})$ were fractioned by electrophoresis on a $10 \%$ SDS-polyacrylamide gel and electroblotted onto Hybond-C nitrocellulose membranes (Amersham Biosciences, Orsay, France). Blots were blocked in Tris-buffered saline containing $0.1 \%$ Tween (TBS-T) and supplemented with $4 \%$ milk powder, subsequently incubated overnight at $4^{\circ} \mathrm{C}$ in this buffer with rabbit antibody directed against Krox20 (1: 1000; Covance, Berkeley, CA), and finally exposed to an anti-rabbit secondary antibody conjugated with HRP (Amersham Biosciences) in TBS-T for $1 \mathrm{~h}$ at room temperature. Blots were developed using the ECL reagents (Amersham Biosciences) according to the manufacturer's instructions. The relative intensities of the bands in Western blotting analyses were quantified using the Image Gauge program.

Immunohistochemistry. Nerves were collected, fixed in $4 \%$ paraformaldehyde for $2 \mathrm{~h}$, incubated overnight at $4^{\circ} \mathrm{C}$ in $20 \%$ sucrose, embedded in Tissue-Tek OCT compound (Gassalem, Limeil-Brévannes, France), and frozen in isopentane $\left(-60^{\circ} \mathrm{C}\right)$. Twenty-micrometer-thick longitudinal or transversal sections were collected using a Leica (Nussloch, Germany) cryotome. Sections were incubated for $30 \mathrm{~min}$ in $0.1 \mathrm{M}$ PBS containing $5 \%$ normal goat serum and $0.25 \%$ Triton X-100 and then overnight at $4^{\circ} \mathrm{C}$ with the following primary antibodies: a rabbit polyclonal anti-Sox 2 antibody (1:150; Millipore, Bedford, MA), a goat polyclonal anti-SCIP antibody (1:50; Santa Cruz Biotechnology, Santa Cruz, CA), a rabbit polyclonal anti-Krox20 antibody (1:50; Covance), a rat polyclonal antiMBP antibody (1:100; Millipore), and a mouse monoclonal neurofilament 2H3 antibody (1:500; Developmental Studies Hybridoma Bank, Iowa city, IA). Sections were then incubated for $1 \mathrm{~h}$ with the appropriate fluorophore-conjugated secondary antibody (Jackson ImmunoResearch, West Grove, PA). For bromodeoxyuridine (BrdU) detection, sections were treated for $10 \mathrm{~min}$ at $37^{\circ} \mathrm{C}$ with $2 \mathrm{~N} \mathrm{HCl}$ in $0.1 \mathrm{M}$ PBS containing $0.25 \%$ Triton $\mathrm{X}-100$, washed twice in $0.1 \mathrm{~m}$ borate buffer, $\mathrm{pH} 8.5$, and incubated at $4^{\circ} \mathrm{C}$ with a rat anti-BrdU antibody (1:100; Oxford Biotech, Oxford, UK), which was subsequently revealed with a biotinylated antirat antibody (1:100; Jackson ImmunoResearch) coupled to Cy3-labeled streptavidin (1:200; Jackson ImmunoResearch). Nuclei were counterstained with Hoechst 33342 or Sytox Green. Sections were mounted in Aqua poly/Mount (Polysciences, Warrington, PA) and analyzed on Leica DMRD and TCS 4D confocal microscopes. For each section, proportions of Sox2- and SCIP-positive cells were quantified in several fields of at least 100 cells and corresponding to lesioned areas, as indicated by increased proportion of SCIP- or Sox2-positive cells. The results shown are the averages $\pm \mathrm{SD}$ for at least 30 serial sections, $60 \mu \mathrm{m}$ apart, from a minimum of three animals for each time point. Statistical significance was evaluated using the Student's $t$ test.

Cell proliferation assay. The rate of cell proliferation was estimated by BrdU incorporation. Two intraperitoneal injections of BrdU $(60 \mathrm{mg} / \mathrm{kg}$ body weight; Sigma) were performed at $2 \mathrm{~h}$ intervals, and the animals were killed $2 \mathrm{~h}$ after the second injection. Sciatic nerves were collected and processed for BrdU immunostaining, and nuclei were counterstained with bisbenzimide (Hoechst 33342; Sigma) or Sytox Green (Invitrogen, San Diego, CA) as indicated below. The number of BrdUpositive nuclei and the total number of nuclei were counted from 20 serial sections $(20 \mu \mathrm{m}), 20$ or $40 \mu \mathrm{m}$ apart, in lesioned regions as attested by SCIP or Sox 2 immunochemistry on adjacent sections. Results shown

injection site; $M$, medial, $5 \mathrm{~mm}$ away from the injection site; $D$, distal, $10 \mathrm{~mm}$ away from the injection site. Control mice without $\mathrm{Cr}$ (Krox20 $0^{\text {lacZ/flox }}, R 26$; data not shown), or injected with DMSO only, do not show second exon excision. $\boldsymbol{e}, \boldsymbol{f}$, Krox20 Western blotting analysis in protein extracts prepared from sciatic nerves from wild-type (WT) and Krox $20^{\text {Crefflox }} \mathrm{P} 1, \mathrm{P} 4, \mathrm{P} 10$, and $\mathrm{P} 28$ animals $(\boldsymbol{e})$ and Krox $20^{\text {lacZ/flox }}$ and Krox $20^{\text {lacz/flox }}, R 26$-CreER ${ }^{T}$ animals $(\boldsymbol{f})$, intraperitoneally TM or focally $0 \mathrm{HT}$ injected and analyzed 3, 8, or $28 \mathrm{~d}$ after the last injection. $\boldsymbol{e}$, Note the progressive decrease in Krox20 protein level in Krox20 crefflox (Mut) compared with wild-type (WT) animals from P1 (no decrease), P4 (50\% reduction), P10 (50\% reduction), and P28 (90\% reduction) as estimated by the relative intensities of the bands. $f$, Twenty-eight days after intraperitoneal TM injection, the analysis of three Krox $20^{\text {lacz/flox }}$, $R 26-C r e E R^{T}$ animals revealed 40,60, and 40\% reductions in Krox20 protein levels, respectively, compared with the control $\left(\right.$ Krox2 $0^{\text {lacz/flox }}$ ). After focal OHT injection, Krox20 protein levels are reduced by $\sim 40 \%$ from 3 d after injection. are the averages \pm SD from three to four animals for each time point. Statistical significance was evaluated using the Student's $t$ test.

Electron microscopy. Sciatic nerves were fixed for $3 \mathrm{~h}$ in $2.5 \%$ glutaraldehyde in Soerensen's buffer and osmificated for $1 \mathrm{~h}$ in $2 \% \mathrm{OsO}_{4}$ (Polysciences). Nerves were rinsed in Soerensen's buffer, dehydrated in graded acetone, and embedded in Epon 812-Araldite. For light microscopy analysis, sections were stained with toluidine blue. Ultrathin sections were stained with uranyl acetate and lead citrate and observed with a Philips CM10 electron microscope.

\section{Results}

\section{A conditional Krox20 mutation resulting in amyelination}

The mouse models for defective myelination developed so far on the basis of two Krox20 mutant alleles are of limited use because of the short lifespan of the animals (Topilko et al., 1994; Le et al., 2005a). This lethality is likely attributable to defects in Krox20 activity in other tissues, in particular the hindbrain, where Krox20 inactivation has been shown to result in early, life-threatening perturbations of the respiratory rhythm (Jacquin et al., 1996; Chatonnet et al., 2002). To circumvent this problem, we generated a mutation allowing only transient expression of Krox 20. Such a mutation may not dramatically affect tissues in which the gene is normally transiently expressed, as the hindbrain. In contrast, if Krox20 expression is constantly required for Schwann cell myelination, this type of mutation should lead to a phenotype similar to that of a null mutation. To obtain a delayed mutation, we made use of two previously developed Krox20 alleles, Krox $20^{\text {Cre }}$ (Voiculescu et al., 2000) and Krox2 flox (Taillebourg et al., 2002). The Krox $20^{C r e}$ allele consists of an insertion of the gene for the Cre recombinase into the Krox20 locus (Fig. 1a), resulting in Krox20 inactivation and expression of the Cre gene with a pattern that faithfully recapitulates the normal Krox20 pattern (Voiculescu et al., 2000). In the Krox $20^{\text {flox }}$ allele, the second Krox20 exon is flanked by loxP sites (Fig. 1a). This allele behaves like wild type, but excision of the floxed exon by the Cre recombinase results in inactivation of $\operatorname{Krox} 20\left(\right.$ Krox20 $\left.0^{\Delta}\right)$ (Fig. 1a) (Taillebourg et al., 2002) (data not shown).

In myelinating Schwann cells from compound heterozygous Krox $20^{\text {Crelflox }}$ animals, Krox 20 is expected to be expressed from the floxed allele until enough Cre recombinase accumulates to lead to the inactivation of the gene. Monitoring the excision of the floxed exon by PCR analysis of DNA extracted from postnatal day 1 (P1), P4, and P28 sciatic nerve samples indicated that excision had already been initiated at P1 (Fig. $1 b$ ) and progressed with time, affecting more than half of the cells at P4 (compare the intensity of the 160 and 195 bp bands in Fig. 1b), although it did not reach completeness by $\mathrm{P} 28$. This probably results from the presence of nonmyelinating Schwann cells and other cells such as fibroblasts that do not express Krox20. The inactivation of the gene in Schwann cells correlated with a progressive loss of the Krox 20 protein (90\% reduction by P28) (Fig. 1e).

Krox $20^{\text {Cre/flox }}$ animals $(n=9)$ survived until $\sim 6$ weeks. All of them were smaller than control littermates (wild type, Krox $20^{\text {Crel+ }}$, Krox $20^{f l o x /+} ; n=3$ of each type), with a reduction in body weight ranging from 25 to $50 \%$ (data not shown). In addition, Krox $20^{\text {Cre/flox }}$ mutants displayed a specific phenotype involving shivering and impaired walking coordination (supplemental video 1 , available at www.jneurosci.org as supplemental material). In 4- and 6-week-old mutant animals, examination of sciatic nerve semithin transverse sections and electron 

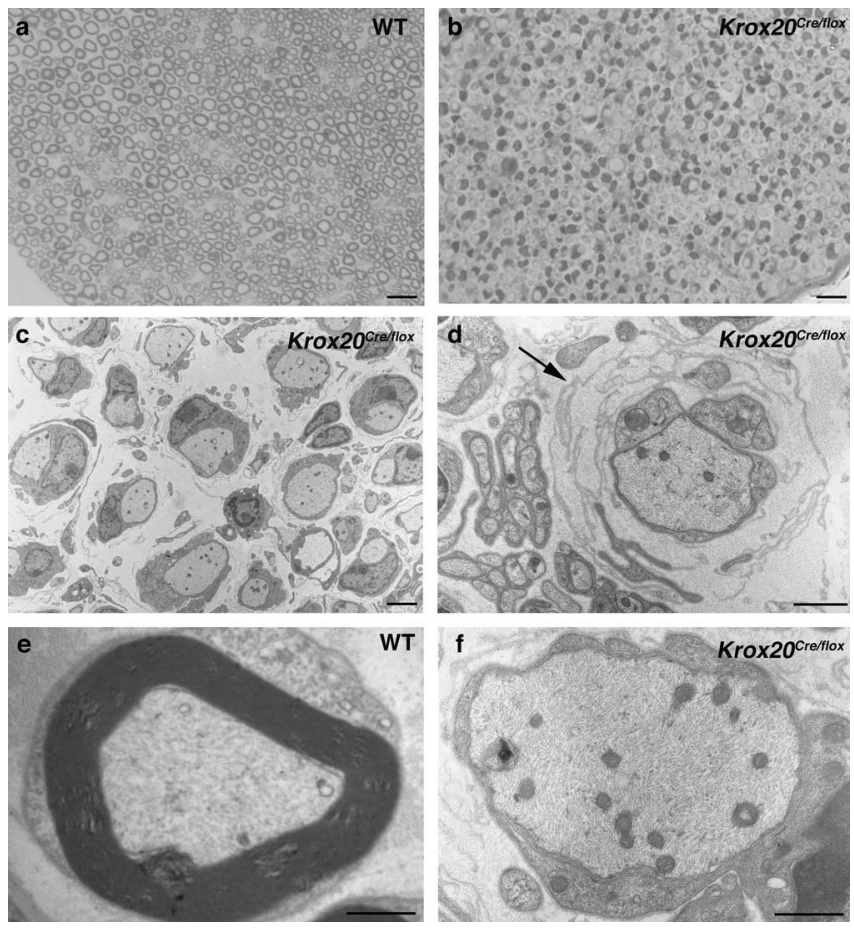

Figure 2. Sciatic nerves from P28 Krox $20^{\text {Crefflox }}$ mice are devoid of myelin. $\boldsymbol{a}, \boldsymbol{b}$, Toluidine blue-stained transverse sections of sciatic nerve from wild-type $(\boldsymbol{a})$ and $K_{\text {rox } 20^{\text {Cre/flox }}(\boldsymbol{b}) \text { mice. }}$ $\boldsymbol{c}-\boldsymbol{f}$, Electron micrographs of sciatic nerve transverse sections from Krox $20^{\text {Cre/flox }}(\boldsymbol{c}, \boldsymbol{d}, \boldsymbol{f})$ and wild-type $(\boldsymbol{e})$ mice, illustrating the absence of myelin in the mutant. Note the intense proliferation of basal membranes ( $\boldsymbol{d}$, arrow) around the axons and the increased number of mitochondria within the axonal cytoplasm (compare $\boldsymbol{e}, \boldsymbol{f}$ ) in the mutants. Scale bars: $\boldsymbol{a}, \boldsymbol{b}, 25 \mu \mathrm{m} ; \boldsymbol{c}, 1.25$ $\mu \mathrm{m} ; \boldsymbol{d}-\boldsymbol{f}, 0.5 \mu \mathrm{m}$. WT, Wild type.

microscopy analysis revealed a complete absence of the myelin sheath, despite normal axonal density (Fig. 2, compare $b-d$ with wild type in $a)\left(89 \pm 2\right.$ and $88 \pm 7$ axonal fibers per $100 \mu \mathrm{m}^{2}$ in wild-type and Krox $20^{\text {Cre/flox }}$ mice, respectively). No evidence of macrophage infiltration or Schwann cell onion bulbs was observed, but extensive, concentric development of basal membranes was frequently found around the axons (Fig. $2 c, d$ ). In addition, the mutant axonal cytoplasm contained a high density of mitochondria (Fig. 2, compare $f$ with wild type in $e$ ), microtubules, and neurofilaments (data not shown) compared with controls, suggesting that myelin deficit resulted in axonal perturbations.

The above analysis demonstrated that Krox $20^{\text {Crelflox }}$ mutant nerves are not myelinated in the adult and raised the issue of whether any myelination occurs during postnatal development. To investigate this question, $\mathrm{P} 4$ sciatic nerve sections were analyzed by electron microscopy. Whereas wild-type animals showed frequent figures of thin myelin (supplemental Fig. 1a,b, available at www.jneurosci.org as supplemental material), Krox $20^{\text {Cre/flox }}$ mutants were almost completely amyelinated (supplemental Fig. $1 c, d$, available at www.jneurosci.org as supplemental material). Attempts of myelination were suggested by the observation of denuded axons associated with mesaxons initiating the wrapping process, but only a few myelin fibers, usually not properly compacted, could be observed in the mutants. A similar analysis performed at $\mathrm{P} 12$ revealed a complete absence of myelin sheath (data not shown). These data suggest that myelination initiation very rarely occurs in the mutant, but when it happens, an abortive myelination process follows it.

There is an apparent discrepancy between the kinetics of es- tablishment of a block in Schwann cell myelination (already fully effective at P4) (supplemental Fig. 1, available at www. jneurosci.org as supplemental material) and the partial loss of the floxed allele and Krox20 protein, with only an approximate twofold reduction at $\mathrm{P} 4$ (Fig. 1b,e). A likely explanation is that the persistence of the unexcised floxed allele is caused by intense proliferation during the perinatal period of immature Schwann cells that have not yet activated Krox20. A significant proportion of these cells may continuously attempt to engage in myelination, expressing Krox20, and therefore maintaining some protein level in the nerve. However, these cells that rapidly inactivate the gene are not able to proceed further along the myelination pathway.

In conclusion, our data indicate that the delayed Krox20 inactivation results in peripheral amyelination and that this phenotype is maintained from birth until $\geq 6$ weeks, suggesting that inactivation of Krox20 definitively prevents myelination, unlike the SCIP/Oct6 knock-out (Jaegle et al., 1996).

\section{Krox 20 is required for myelin maintenance}

The data obtained from the Krox $20^{\text {Cre/flox }}$ mutant did not address the issue of whether Krox 20 could be required only during the initiation of the myelination process and might be dispensable later on. To investigate this possibility, we made use of the floxed allele to develop another conditional mutant. We generated compound heterozygous mutants carrying the floxed allele and a Krox $20^{\text {lac } Z}$ allele (Fig. 1a), which is null in terms of Krox20 activity (Schneider-Maunoury et al., 1993), together with the R26$\mathrm{CreER}^{T}$ transgene. The latter consists in a TM-inducible Cre recombinase $\left(\mathrm{CreER}^{\mathrm{T}}\right.$ ) expressed from the ubiquitous Rosa26 locus (Vooijs et al., 2001). Krox20 lacZ/flox,$R 26-C r e E R^{T}$ animals were first analyzed in a systemic protocol of TM administration. Three-month-old animals received an intraperitoneal injection of TM (two $1 \mathrm{mg}$, i.p. injections per day for $5 \mathrm{~d}$ ) and were killed $28 \mathrm{~d}$ after the last injection. Analysis of sciatic nerve DNA revealed a partial excision of Krox20 second exon (Fig. 1c) that correlated with a decreased level of the Krox20 protein (Fig. 1f). Krox20 lacZ/flox, R26$\mathrm{CreER}^{T}$ animals $(n=4)$ displayed discrete clinical signs from 5 to $7 \mathrm{~d}$ after the last injection (data not shown). They had a retracted back paw and were more static than controls (oil-injected Krox $20^{\text {lac } Z / f l o x}$, R26-CreER ${ }^{T}$; TM-injected Krox20 lacZ/+, R26-CreER ${ }^{T}$; TM-injected Krox $20^{\text {lac } Z / f l o x} ; n=2$ for each type).

Observation of semithin transverse sections of sciatic nerves from killed animals indicated a normal density of myelinated axons [ $80 \pm 2$ axonal fibers per $100 \mu^{2}$ in Krox20 ${ }^{\text {lacZlflox }}, R 26-$ $\mathrm{CreER}^{T}$ animals (Fig. $\left.3 a\right)(n=4)$ compared with $84 \pm 1$ in controls $(n=3)]$. However, electron microscopy revealed the presence of groups of two to three axons without myelin sheath (Fig. $3 b$, arrows), distinguishable from unmyelinated small-caliber axons that were preserved. In addition, some nodes of Ranvier were enlarged (data not shown), and macrophages loaded with myelin debris were observed in the endoneurial space (Fig. $3 c$ arrow). This macrophagic invasion was associated with accumulation of concentric layers of Schwann cell basal membranes (Fig. 3d, arrows) and with onion bulb formations (Fig. $3 e$, arrows). Attempts of remyelination were suggested by the observation of denuded axons associated with mesaxons initiating the wrapping process (Fig. $3 f$, arrow and inset) and of myelin sheaths abnormally thin in relation to the axon caliber (Fig. $3 g$, arrow). All of these features were not observed in control animals (data not shown).

Because of the relatively discrete histological phenotype, we found the present protocol not really appropriate to generate a useful model for additional studies. Repeating the TM injection twice did not radically change the situation, although it increased 

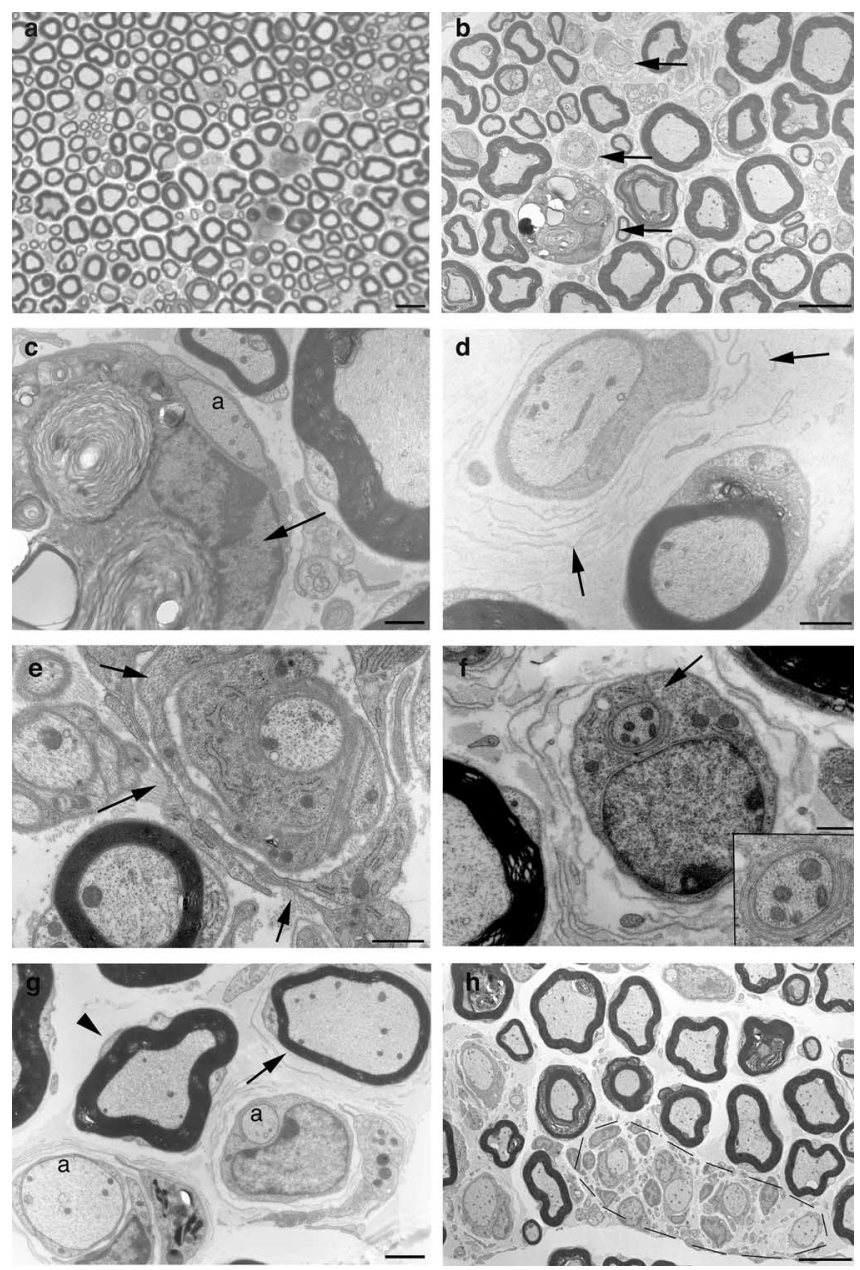

Figure 3. Inactivation of Krox20 by intraperitoneal TM injection leads to discrete demyelination. The Krox $20^{\text {lacz/flox }}, R 26$-CreER ${ }^{T}$ animals were given injections for $5 \mathrm{~d}(\boldsymbol{a}-\boldsymbol{g})$ or twice for $5 \mathrm{~d}(\boldsymbol{h})$, as indicated in Materials and Methods, and killed $28 \mathrm{~d}$ after the last injection. $\boldsymbol{a}$, Toluidine blue-stained semithin section revealing normal density of axonal fibers. $\boldsymbol{b}-\boldsymbol{g}$, Micrographs of ultrathin sections illustrating the observation of denuded axons ( $\boldsymbol{b}$, arrows), of macrophages that have entered the Schwann cell cytoplasm ( $\boldsymbol{c}$, arrow) leading to myelin disruption around the axon (a), of intense proliferation of basal membranes ( $\boldsymbol{d}$, arrows), of onion bulbs (e, arrows), of mesaxons starting to wrap the axon ( $\boldsymbol{f}$, arrow and inset showing a higher magnification of the area), and of myelin sheaths abnormally thin ( $\boldsymbol{g}$, arrow) compared with a normal myelinated axon ( $\boldsymbol{g}$, arrowhead) [note the presence of completely denuded axons (a)]. These latter characteristics suggest that remyelination is occurring. $\boldsymbol{h}$, Larger groups of denuded axons (encircled by the dotted line) are observed after double TM treatment. Scale bars: $\boldsymbol{a}, 25 \mu \mathrm{m} ; \boldsymbol{b}$, $\boldsymbol{h}, 2.5 \mu \mathrm{m} ; \boldsymbol{c}-\boldsymbol{g}, 0.5 \mu \mathrm{m}$.

the severity of the clinical signs (supplemental video 2, available at www.jneurosci.org as supplemental material) and led to the presence of larger groups of axons without myelin (Fig. $3 h$ ). We reasoned that the low frequency of Schwann cell dedifferentiation was likely caused by inefficient excision of the Krox20 second exon, itself resulting from poor access of intraperitoneally injected TM to Schwann cells within the nerve (Leone et al., 2003). We therefore decided to perform direct injections of OHT, a water-soluble derivative of TM, into the sciatic nerve. The animals received a unique injection of OHT into one leg, together with an injection of the carrier into the other leg, and were killed 3,8 , and $28 \mathrm{~d}$ after injection. This led to more severe clinical signs than the $5 \mathrm{~d}$ TM peritoneal injection protocol, with systematically retracted and weak paws corresponding to the OHT-injected leg and unbalanced walking posture $(n=4,5$, and 3 at 3,8 , and $28 \mathrm{~d}$, respectively). As early as $3 \mathrm{~d}$ after the injection, electron micros-
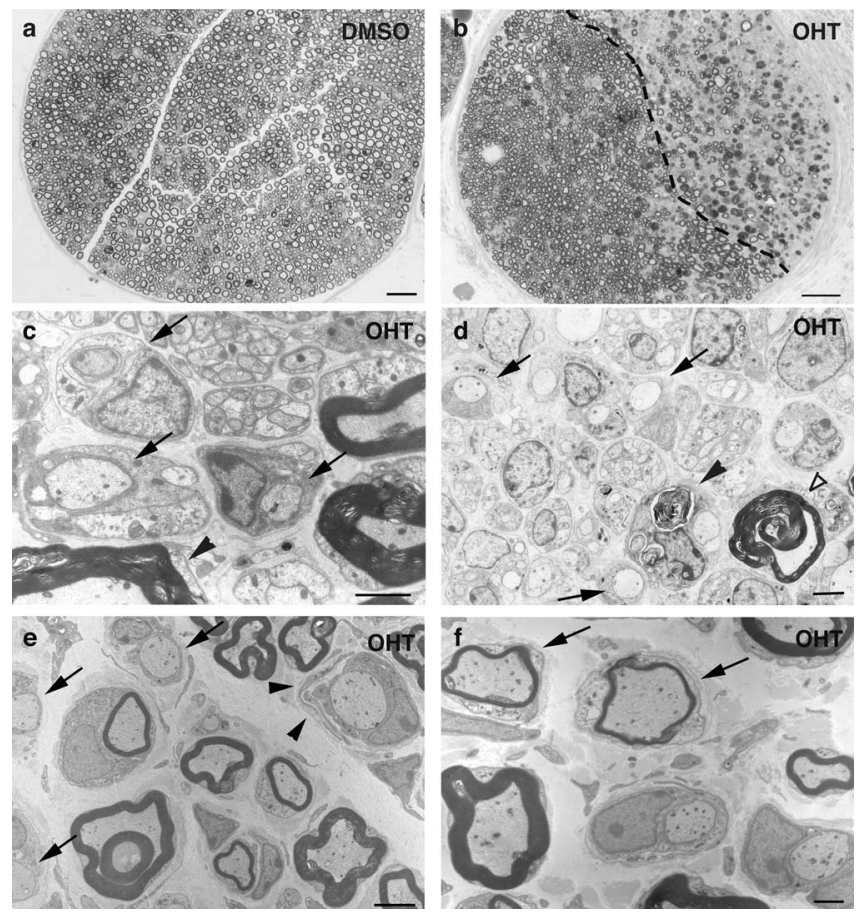

Figure 4. Inactivation of $\mathrm{Krox} 20$ by focal injection of $\mathrm{OHT}$ in the sciatic nerve leads to massive demyelination. $\boldsymbol{a}, \boldsymbol{b}$, Semithin, transverse toluidine blue-stained sections of carrier $(\boldsymbol{a})$ and $\mathrm{OHT}$-injected $(\boldsymbol{b})$ sciatic nerves analyzed $8 \mathrm{~d}$ after injection. Severe myelin depletion is observed in the right half of the $\mathrm{OHT}$-injected nerve. $c-f$, Electron microscopy analysis of $\mathrm{OHT}$-injected sciatic nerve prepared $3 \mathrm{~d}(\boldsymbol{c}), 8 \mathrm{~d}(\boldsymbol{d})$, or $28 \mathrm{~d}(\boldsymbol{e}, \boldsymbol{f})$ after injection. $\boldsymbol{c}$, Three days after the injection, myelin presents aspect of degradation (arrowhead) and some denuded axons are detected (arrows). $\boldsymbol{d}$, Eight days after $\mathrm{OHT}$ injection, some areas are primarily devoid of myelin, with numerous denuded axons (arrows) and presence of macrophages (filled arrowhead) and of outfolded myelin (open arrowhead). Discrete cytoplasmic disorganizations in bundles of unmyelinated fibers (Remak) is occasionally observed in both experimental ( $\boldsymbol{c}, \boldsymbol{d}$ ) and control animals and is likely to result from tissue fixation. $\boldsymbol{e}, \boldsymbol{f}$, Twenty-eight days after the injection, onion-bulb formations ( $\boldsymbol{e}$, arrowheads) are observed and numerous axons remain denuded ( $\boldsymbol{e}$, arrows), whereas others are wrapped with abnormally thin myelin sheaths ( $\boldsymbol{f}$, arrows). All of these observations were performed in the region proximal to the injection site (see Fig. $1 b$ ). Scale bars: $\boldsymbol{a}, \boldsymbol{b}, 50 \mu \mathrm{m} ; \boldsymbol{e}, 5 \mu \mathrm{m} ; \boldsymbol{c}, \boldsymbol{d}, \boldsymbol{f}, 1 \mu \mathrm{m}$

copy analysis of the OHT-injected sciatic nerve revealed that the area of injection was subject to myelin degradation, with some axons already denuded $(n=4)$ (Fig. $4 c)$. These observations were consistent with immunofluorescence analyses indicating correlated loss of Krox20 and of the myelin protein MBP in areas close to the injection point (supplemental Fig. 2, available at www.jneurosci.org as supplemental material). No such phenotypes were observed in the carrier-injected side or in control animals given injections of OHT (data not shown). Eight days after the injection, myelin depletion was more severe, with the observation of regions almost devoid of myelin, compared with carrierinjected controls (Fig. $4 a, b, d)(n=5)$. The presence of macrophages and outfolded myelin (Fig. $4 d$ ) indicated that myelin was actively degraded. Twenty-eight days after injection, the level of macrophagic infiltration was reduced, no signs of axonopathy were detected, but onion bulb formations were observed (Fig. 4e, arrowheads) and numerous axons remained denuded (Fig. 4e, arrows) $(n=3)$, indicating that demyelination is long lasting and possibly permanent. In addition, the presence of numerous mesaxons wrapping around the axons (data not shown) and of axons with abnormally thin myelin sheaths (Fig. $4 f$, arrows) suggested that attempts of remyelination were occurring at the same time. Analysis of sciatic nerve DNA indicated that clinical and 

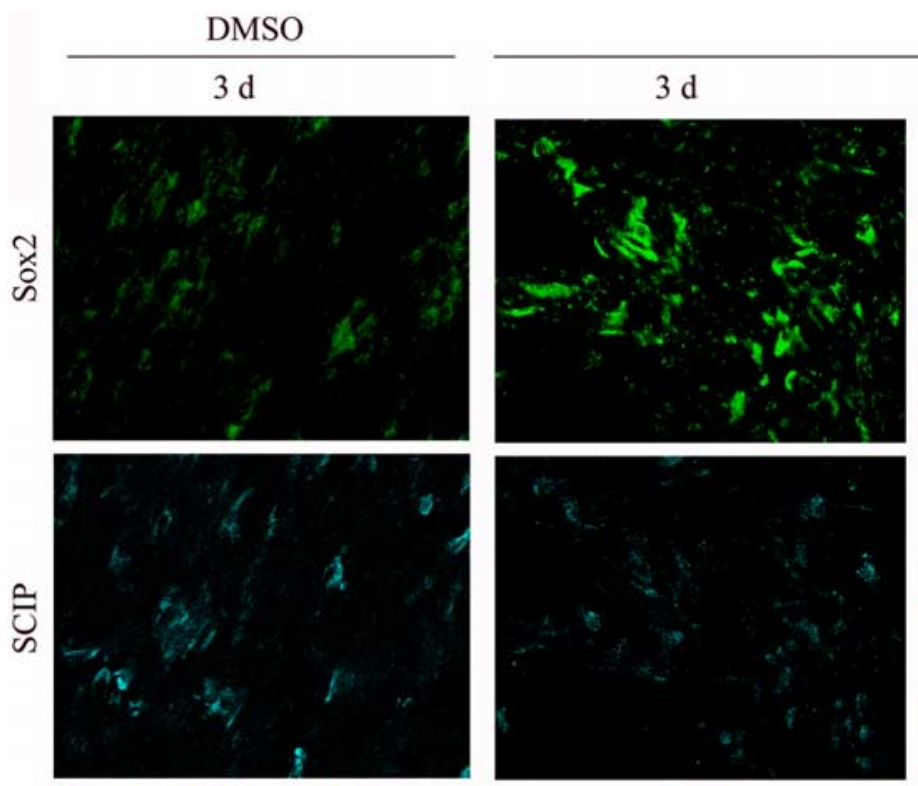

\section{OHT}
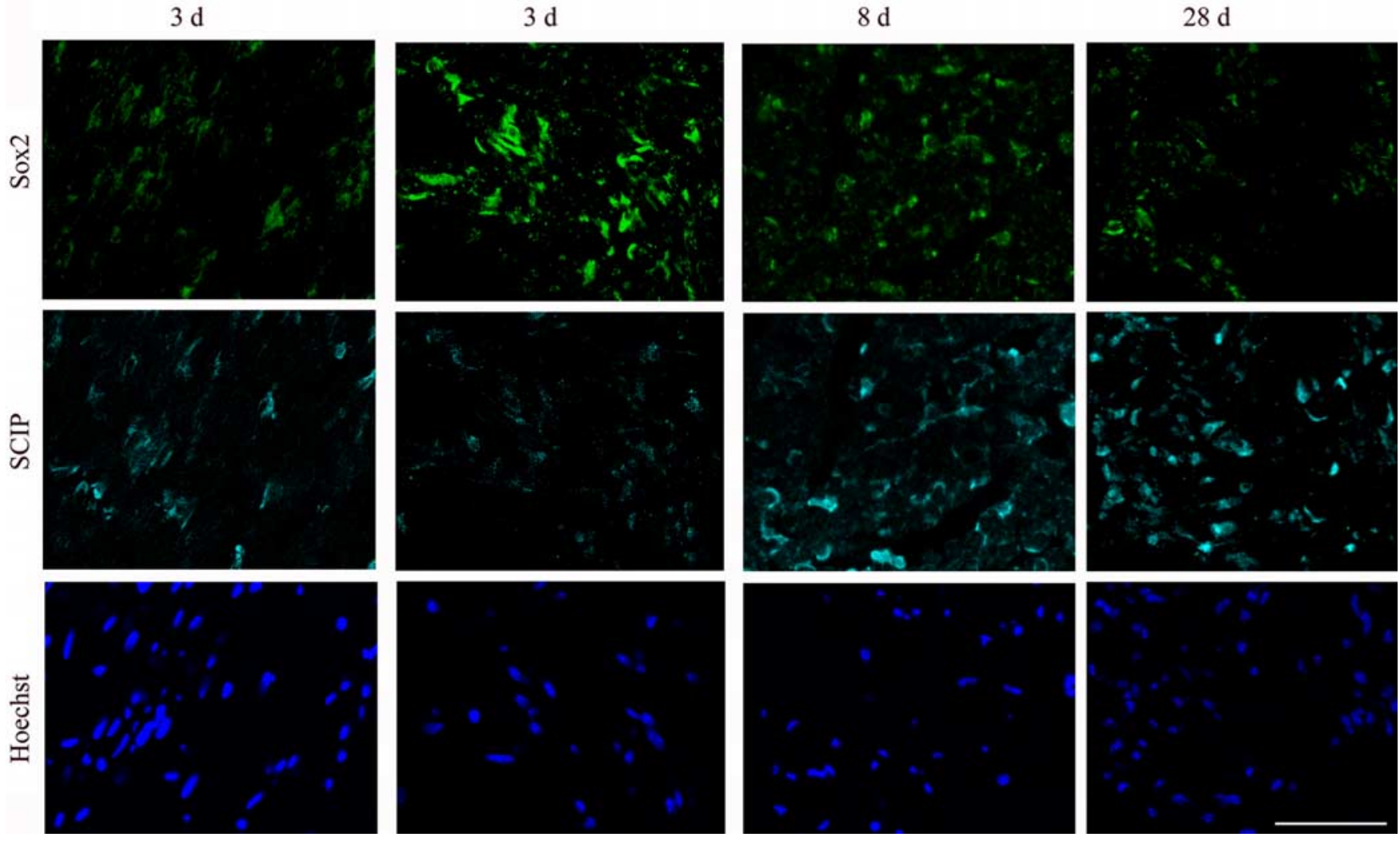

Figure 5. Krox20 inactivation results in transient and long-term expression of Sox2 and SCIP Schwann cell markers, respectively. Sciatic nerve sections were prepared 3, 8, or $28 \mathrm{~d}$ after DMSO or OHT injections of Krox2 ${ }^{\text {lacz/flox }}, R 26$-CreER ${ }^{T}$ mice and immunolabeled for Sox2 (green), a marker for immature Schwann cells, and SCIP (blue-green), a Schwann cell marker not expressed in mature myelinating cells. Cell nuclei were counterstained with Hoechst 33342 (dark blue). Note that OHT injection leads to rapid and transient accumulation of Sox2, whereas SCIP induction occurs later (8 d) but lasts longer. Scale bar, $55 \mu \mathrm{m}$.

histological phenotypes correlated with partial excision of Krox20 second exon (Fig. 1d) and reduced levels of Krox20 protein (Fig. $1 f$ ), which were observed as early as $3 \mathrm{~d}$ after injection. In addition, it showed that excision was observed at least $5 \mathrm{~mm}$ away from the site of OHT injection, suggesting that this compound can efficiently diffuse along the nerve (Fig. 1d).

In conclusion, altogether our observations establish that Krox 20 is constantly required for the maintenance of the myelin sheath and that its inactivation leads to rapid demyelination, accompanied by remyelination attempts.

\section{Conditional Krox 20 knock-out results in the accumulation of} immature Schwann cells and increased cell proliferation

Because focal Krox20 inactivation results in demyelination, we analyzed its consequences at the cellular level, on Schwann cell gene expression and proliferation. To evaluate the Schwann cell differentiation status, we analyzed the expression of Sox 2 and SCIP/Oct6 by immunofluorescence. Sox 2 constitutes a marker of immature Schwann cells, whereas SCIP is also expressed in promyelinating and early myelinating cells and both markers are expressed at only low levels in mature myelinating Schwann cells (Blanchard et al., 1996; Jaegle et al., 1996; Le et al., 2005a). Whereas Krox20 lacZ/flox, R26-CreER ${ }^{T}$ sciatic nerve injection with DMSO alone did not modify Sox2 and SCIP expression (5 $\pm 1 \%$ of the Schwann cells were Sox 2 or SCIP positive after $3 \mathrm{~d}$; no significant variation of these proportions were observed at 8 and $28 \mathrm{~d}$ after the injection), OHT injection resulted in the accumulation of both proteins (Fig. 5) (data not shown). However, the kinetics were strikingly different. Sox 2 was rapidly induced by OHT, with $42.3 \pm 9.6 \%$ of positive cells $3 \mathrm{~d}$ after injection $(p<$ 0.001 , compared with DMSO injection), and returned progressively to basal level afterward $[21.2 \pm 7 \%$ of positive cells after $8 \mathrm{~d}$ $(p<0.01)$ and $5.7 \pm 3 \%$ after $28 \mathrm{~d}]$. In contrast, the increase in SCIP protein level in response to OHT injection was slower. It was only slightly elevated $3 \mathrm{~d}$ after OHT injection, but it reached a high level after $8 \mathrm{~d}(34 \pm 10 \% ; p<0.01)$, which was maintained for at least $28 \mathrm{~d}(37.4 \pm 6.8 \% ; p<0.01)$. Such modifications in Sox 2 and SCIP expression were also observed up to at least $5 \mathrm{~mm}$ away from the OHT injection site (data not shown), in accordance with the data on Krox20 second exon deletion (Fig. 1d). Altogether, these results suggest that Schwann cells that lost Krox20 adopt immature Schwann cell identity and subsequently attempt to re-engage into the myelination process (see Discussion).

To investigate whether these changes in Schwann cell differentiation were also accompanied by modifications in the rate of cell proliferation, we estimated the proportion of cells in $S$ phase by BrdU incorporation (Fig. 6a,b). Whereas control or DMSOinjected nerves contained a very low percentage of cells in $S$ phase $(0.2-2 \%)$, this percentage surpassed $10 \%$ within $3 \mathrm{~d}$ in the cases of OHT injection (Fig. $6 c$ ). This percentage then progressively decreased to return to control levels $28 \mathrm{~d}$ after OHT injection (Fig. 6c). These data suggest that OHT injection in Krox $20^{\text {lacZ/flox }}$, $R 26-C_{r e E R}^{T}$ sciatic nerve results in a transient burst in cell proliferation, which parallels the elevation in Sox2 expression. Therefore, demyelination induced by conditional Krox 20 knock- 

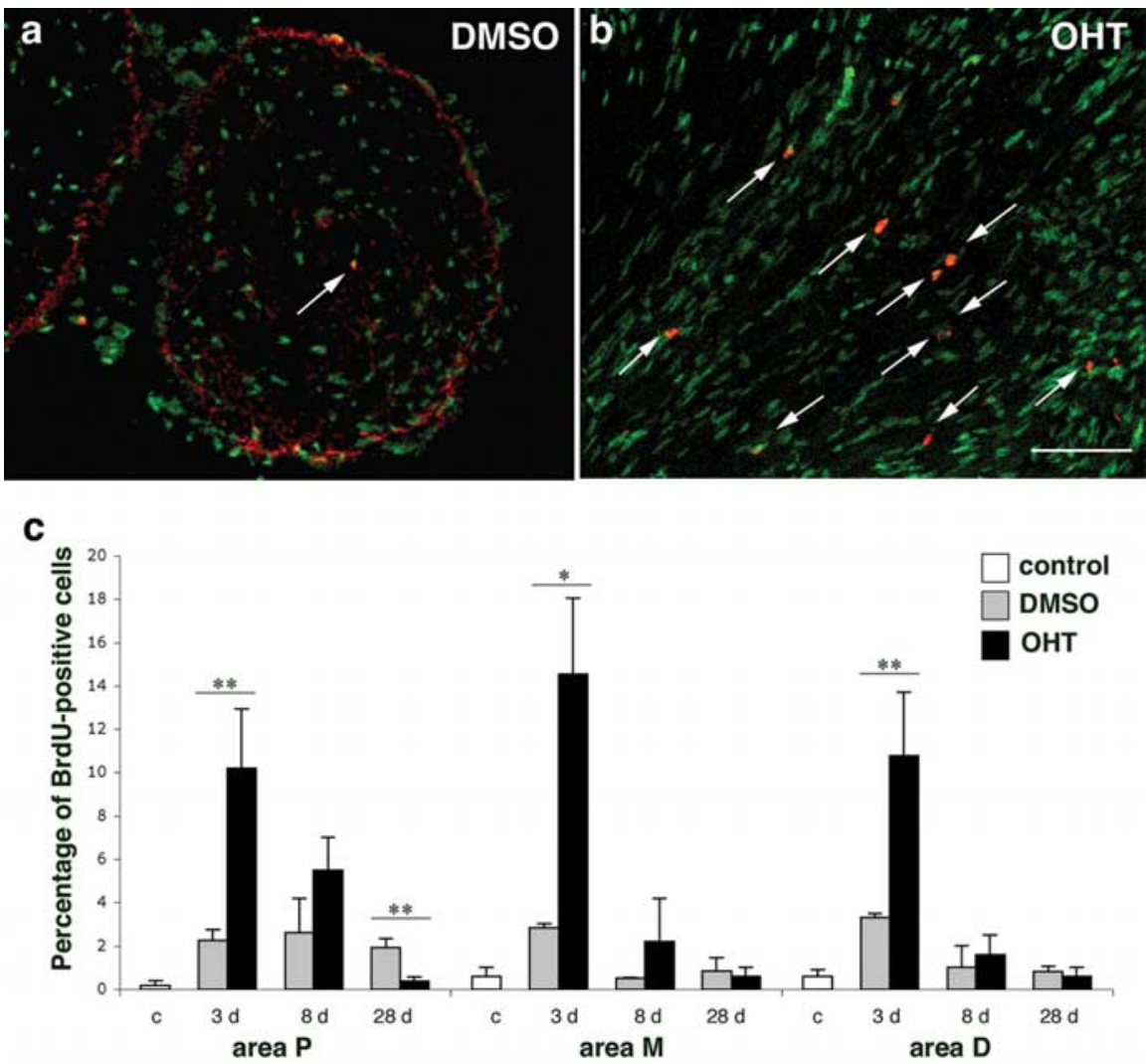

Figure 6. Krox20 inactivation results in a transient increase in Schwann cell proliferation. Cell proliferation was estimated by BrdU incorporation. The animals were given intraperitoneal injections of BrdU, the incorporation of which in DNA was subsequently revealed by immunostaining of sciatic nerve sections. Nuclei were counterstained with Hoechst 33342 or Sytox Green. $\boldsymbol{a}$ $\boldsymbol{b}$, BrdU incorporation $8 \mathrm{~d}$ after DMSO (a) and OHT $(\boldsymbol{b})$ injections into the sciatic nerve of Krox $20^{\text {lacZ/flox }}, R 26-C r e E R^{T}$ mice. Nuclei are visualized with Sytox green (green), and those in S phase (arrows) are labeled with anti-BrdU antibodies (red). Scale bar, $75 \mu \mathrm{m}$. c, Estimation of the percentage of BrdU-positive nuclei in sections of the sciatic nerves from noninjected (control), DMSO-injected, and $\mathrm{OHT}$-injected Krox2 ${ }^{\text {lacz/flox }}, R 26$-CreER ${ }^{T}$ mice 3, 8, and $28 \mathrm{~d}$ after injection. Quantitations were performed from lesioned areas (see Materials and Methods). The sections were derived from the proximal (P), medial (M), and distal (D) areas respective to the site of injection, as described in the legend to Figure $1 b$. Note that $\mathrm{OHT}$ treatment significantly increases the percentage of BrdU-positive cells within $3 \mathrm{~d}$ in all areas and that this level progressively returns to normal within $28 \mathrm{~d}$. Values are means \pm SD of at least three mice. Statistical significance was analyzed using the Student's $t$ test: ${ }^{*} p<0.02$; $^{* *} p<0.01$

out appears to be accompanied by the coincidental appearance of immature Schwann cells and reactivation of cell proliferation.

\section{Discussion}

Krox20 constitutes a key regulator of myelination in Schwann cells. In this study, we have used Krox 20 conditional mutations to further investigate the function of the gene and the mechanisms involved in myelin maintenance. Several major conclusions can be reached: (1) unlike SCIP/Oct6, Krox20 is absolutely required for onset of myelination in the PNS; (2) it is also constantly required for the maintenance of the myelin sheath; and (3) demyelination after Krox20 inactivation involves Schwann cell dedifferentiation and is very rapid. This suggests that myelin maintenance is a dynamic process and that Krox 20 acts as a reversible molecular switch governing both myelination and demyelination programs.

Molecular genetic studies have highlighted the heterogeneity of the peripheral neuropathies linked to Krox20. So far only missense mutations in the coding sequence have been observed. The type of pathology (CMT, CHN, or DSS), its severity, and age of onset appear to depend on the domain of the protein affected by the mutation as well as on the precise amino acid affected and on the type of substitution (Warner et al., 1998; Timmerman et al.,
1999; Pareyson et al., 2000; Mikesova et al., 2005). Our analyses, which only affect the level of Krox20 expression and its temporal modulation, constitute a first step toward the understanding of its complex role in the control of myelination.

Mice homozygous for null or hypomorphic Krox20 alleles show a block in Schwann cell myelination (Topilko et al., 1994; Le et al., 2005a). However, these animals do not survive beyond 3 weeks after birth, precluding the establishment of whether the block in myelination is transient or definitive. Through the generation of a delayed Krox 20 mutation (Krox $20^{\text {Cre/flox }}$ ), we have been able to circumvent perinatal death presumably attributable to other aspects of Krox20 function (Schneider-Maunoury et al., 1993; Swiatek and Gridley, 1993; Jacquin et al., 1996). Animals carrying this novel mutation survive up to 6 weeks after birth, a stage when peripheral myelination is normally completed. Our data establish that the mutation results in an early and permanent block in myelin formation, indicating that Krox20 is absolutely necessary for peripheral myelination, in contrast to SCIP, the inactivation of which leads to delayed myelination (Jaegle et al., 1996). Krox20 Cre/flox mutants display pathological, histological, and ultrastructural characteristics (Fig. 2) that are very similar to those of CHN in humans, including onset in infancy or early childhood and severe hypomyelination (Harati and Butler, 1985). Early death during infancy, resulting from respiratory failure, has also been reported in a case of CHN (Parman et al., 2004). This suggests that $K r o \times 20^{\text {Cre/flox }}$ mice might constitute an appropriate model for the most severe type of human peripheral myelinopathy.

The analysis of Krox $20^{\text {Cre/flox }}$ mice did not address Krox 20 requirement for myelin maintenance. To investigate this issue, we generated a TM- and OHT-inducible Krox20 conditional mutant. Administration of the inducer resulted in demyelination, accompanied with clinical signs of peripheral neuropathy. Previous experiment showed that Ndrg1-deficient mice are subjected to demyelination after 2 weeks of age, thus constituting a model for early-onset peripheral neuropathy such as CMT4D (Okuda et al., 2004). Although these data suggested a role for Ndrg1 in myelin maintenance from birth, nothing was known about the molecules involved in the maintenance of the myelin sheath after complete myelination. In contrast to a recent study showing that the inducible inactivation of ErbB2, a receptor for neuregulin involved in myelination during development, has no effect on myelin integrity in adult (Atanasoski et al., 2006), our data clearly establish that Krox20 expression is constantly required for myelin maintenance. The histological characteristics of OHT-injected nerves from Krox $20^{\text {lacZ/flox }}$, R26-CreER ${ }^{T}$ animals (Figs. 3, 4) are encountered in human peripheral myelinopathies such as dominant and recessive forms of CMT (CMT1D, CMT4E) (Vallat, 2003; Vallat et al., 2004), in which demyelination is associated 
with Krox20 mutations. This conditional mutation should therefore constitute a useful mouse model for this type of pathology.

Because Krox20 inactivation in mature myelinating Schwann cells leads to demyelination, it is essential to understand what happens at the cellular level. Rapid, transient, and widespread induction of the immature Schwann cell marker, Sox2, and acceleration of cell proliferation parallel demyelination. This is followed by prolonged expression of SCIP/Oct6, a gene expressed in immature, promyelinating, and early myelinating Schwann cells (Arroyo et al., 1998). Accordingly, histological analysis indicated that many Schwann cells are blocked at the promyelination stage, with only a minority of axons showing signs of remyelination. These observations suggest the following interpretations. (1) Large proportions of the immature Schwann cells that appear after the administration of OHT are derived from previously myelinating Schwann cells. This is suggested by the rapid induction of Sox 2 expression in almost half of the cells and also supported by arguments that are discussed below. (2) If these cells are associated with an appropriate axon, they subsequently attempt to reinitiate myelination; however, they fail because of a lack of Krox20 and end up locked in the promyelinating state, like primary differentiating Schwann cells in the case of Krox20 germline null mutation. Our observations also suggest that the promyelinating state cannot be reached directly by demyelinating cells and that they need to go through the immature state. (3) Cells that have not undergone Krox20 inactivation must deposit the thin myelin sheaths observed in our OHT injection experiments around a minority of axons. These cells may derive from Schwann cells or Schwann cell precursors that were located outside of the lesioned area and have been recruited in the remyelination process. Once in the lesion area, these cells escape Krox20 excision because of a rapid decrease in the level of OHT, because of both diffusion and short half-life of this compound (Danielian et al., 1998). Alternatively, these myelinating cells may derive from Schwann cells initially belonging to amyelinated nerve fibers (Remak fibers) located within the lesion area. Such cells have recently been shown to actively proliferate after nerve injury (Murinson et al., 2005).

A surprising feature of the demyelination associated with Krox20 inactivation is its rapidity $(<3 \mathrm{~d})$. This could be explained by two nonexclusive mechanisms, which we will refer to as "passive" and "active." According to the passive hypothesis, Krox20 inactivation results in a block of expression of an essential myelin protein(s) that is highly unstable, the elimination of which leads to general myelin dysfunction and degradation. In the second scenario, Krox20 loss-of-function leads to the engagement of a specific program of dedifferentiation that involves active myelin destruction. This latter interpretation is supported by the following observations. (1) RNA profiling experiments indicate that Krox20 is not only responsible for the activation of myelinationspecific genes but also for the repression of immature Schwann cell-specific genes (Nagarajan et al., 2001; P. Topilko, S. Le Crom, and P. Charnay, unpublished data). (2) More specifically, Krox20 has been proposed to repress Sox 2 and c-jun, genes that have been shown to be involved in maintaining the immature stage (Le et al., 2005a; Parkinson et al., 2004). It is therefore possible that the repression by Krox 20 of the demyelination program is, at least in part, mediated by Sox 2 and c-Jun, consistent with our data showing an upregulation of Sox2 after Krox20 inactivation (Fig. 5). (3) As discussed below, loss of Krox20 expression likely constitutes a key step in Wallerian degeneration, which involves a dedifferentiation program in Schwann cells leading to active myelin degradation (Stoll and Muller, 1999).
Together, these data suggest that the Schwann cell dedifferentiation program is actually repressed by Krox20. This leads to an extension of the role of Krox20 to a molecular switch that constantly controls the fate of Schwann cells by simultaneously activating myelination and repressing demyelination programs. Such a switch governing two alternative differentiation programs is highly reminiscent of the function of Krox20 in the hindbrain, where it promotes odd-numbered and represses even-numbered rhombomere identities (Seitanidou et al., 1997; Giudicelli et al., 2001; Voiculescu et al., 2001). This similarity raises the possibilities that some of the direct transcriptional targets of Krox20 might be common between the two situations and that Krox20 may play a similar dual role in the other developmental systems. The myelin degradation and attempts of remyelination observed after Krox20 inactivation are very similar, both in their kinetics and characteristics (including the increase in cell proliferation), to Wallerian degeneration and regeneration after nerve cryolesion (Stoll and Muller, 1999). Because in this latter case nerve degeneration/regeneration is accompanied by extinction and then reinduction of Krox20 (Ghislain et al., 2002) and because Krox20 expression is known to be dependent on axonal contact (Murphy et al., 1996), our data suggest a likely mechanism for Wallerian degeneration: axonal injury leads to the interruption of the signals that are constantly required for Krox20 transcription in Schwann cells. This results in a rapid decrease in the level of Krox 20 mRNA and protein and subsequently in the concomitant arrest of the myelination program and the initiation of demyelination.

In conclusion, our work shows that cessation of the expression of a single gene results in rapid myelin degradation, demonstrating that myelin maintenance by Schwann cells is a very dynamic process. This novel feature is likely to be important in the development of acquired and chronic peripheral myelinopathies and should be taken into account in the development of future therapies. In addition, it is possible that this property is not restricted to peripheral myelin, and it will be interesting to investigate whether central myelin behaves similarly.

\section{References}

Arroyo EJ, Bermingham Jr JR, Rosenfeld MG, Scherer SS (1998) Promyelinating Schwann cells express Tst-1/SCIP/Oct-6. J Neurosci 18: 7891-7902.

Atanasoski S, Scherer S, Sirkowski E, Leone D, Garratt A, Birchmeier, Suter U (2006) ErbB2 signaling in Schwann cells is mostly dispensable for maintenance of myelinated peripheral nerves and proliferation of adult Schwann cells after injury. J Neurosci 26:2124-2131.

Bellone E, Di Maria E, Soriani S, Varese A, Doria LL, Ajmar F, Mandich P (1999) A novel mutation (D305V) in the early growth response 2 gene is associated with severe Charcot-Marie-Tooth type 1 disease. Hum Mutat 14:353-354.

Blanchard AD, Sinanan A, Parmantier E, Zwart R, Broos L, Meijer D, Meier C, Jessen KR, Mirsky R (1996) Oct-6 (SCIP/Tst-1) is expressed in Schwann cell precursors, embryonic Schwann cells, and postnatal myelinating Schwann cells: comparison with Oct-1, Krox-20, and Pax-3. J Neurosci Res 46:630-640

Boerkoel CF, Takashima H, Bacino CA, Daentl D, Lupski JR (2001) EGR2 mutation R359W causes a spectrum of Dejerine-Sottas neuropathy. Neurogenetics 3:153-157.

Chatonnet F, Thoby-Brisson M, Abadie V, Dominguez del Toro E, Champagnat J, Fortin G (2002) Early development of respiratory rhythm generation in mouse and chick. Respir Physiol Neurobiol 131:5-13.

Danielian PS, Muccino D, Rowitch DH, Michael SK, McMahon AP (1998) Modification of gene activity in mouse embryos in utero by a tamoxifeninducible form of Cre recombinase. Curr Biol 8:1323-1326.

Ghislain J, Charnay P (2006) Control of myelination in Schwann cells: a Krox 20 cis-regulatory element integrates Oct6, Brn2 and Sox10 activities. EMBO Rep 7:52-58. 
Ghislain J, Desmarquet-Trin-Dinh C, Jaegle M, Meijer D, Charnay P, Frain M (2002) Characterisation of cis-acting sequences reveals a biphasic, axondependent regulation of Krox20 during Schwann cell development. Development 129:155-166.

Giudicelli F, Taillebourg E, Charnay P, Gilardi-Hebenstreit P (2001) Krox-20 patterns the hindbrain through both cell-autonomous and non cell-autonomous mechanisms. Genes Dev 15:567-580.

Harati Y, Butler IJ (1985) Congenital hypomyelinating neuropathy. J Neurol Neurosurg Psychiatry 48:1269-1276.

Jacquin TD, Borday V, Schneider-Maunoury S, Topilko P, Ghilini G, Kato F, Charnay P, Champagnat J (1996) Reorganization of pontine rhythmogenic neuronal networks in Krox-20 knockout mice. Neuron 17:747-758.

Jaegle M, Mandemakers W, Broos L, Zwart R, Karis A, Visser P, Grosveld F, Meijer D (1996) The POU factor Oct-6 and Schwann cell differentiation. Science 273:507-510.

Le N, Nagarajan R, Wang JY, Araki T, Schmidt RE, Milbrandt J (2005a) Analysis of congenital hypomyelinating Egr2Lo/Lo nerves identifies Sox2 as an inhibitor of Schwann cell differentiation and myelination. Proc Natl Acad Sci USA 102:2596-2601.

Le N, Nagarajan R, Wang JY, Svaren J, LaPash C, Araki T, Schmidt RE, Milbrandt J (2005b) Nab proteins are essential for peripheral nervous system myelination. Nat Neurosci 8:932-940.

Leone DP, Genoud S, Atanasoski S, Grausenburger R, Berger P, Metzger D, Macklin WB, Chambon P, Suter U (2003) Tamoxifen-inducible gliaspecific Cre mice for somatic mutagenesis in oligodendrocytes and Schwann cells. Mol Cell Neurosci 22:430-440.

Mikesova E, Huhne K, Rautenstrauss B, Mazanec R, Barankova L, Vyhnalek M, Horacek O, Seeman P (2005) Novel EGR2 mutation R359Q is associated with CMT type 1 and progressive scoliosis. Neuromuscul Disord 15:764-767.

Murinson BB, Archer DR, Li Y, Griffin JW (2005) Degeneration of myelinated efferent fibers prompts mitosis in Remak Schwann cells of uninjured C-fiber afferents. J Neurosci 25:1179-1187.

Murphy P, Topilko P, Schneider-Maunoury S, Seitanidou T, Baron-Van Evercooren A, Charnay P (1996) The regulation of Krox-20 expression reveals important steps in the control of peripheral glial cell development. Development 122:2847-2857.

Nagarajan R, Svaren J, Le N, Araki T, Watson M, Milbrandt J (2001) EGR2 mutations in inherited neuropathies dominant-negatively inhibit myelin gene expression. Neuron 30:355-368.

Okuda T, Higashi Y, Kokame K, Tanaka C, Kondoh H, Miyata T (2004) Ndrg1-deficient mice exhibit a progressive demyelinating disorder of peripheral nerves. Mol Cell Biol 24:3949-3956.

Pareyson D, Taroni F, Botti S, Morbin M, Baratta S, Lauria G, Ciano C, Sghirlanzoni A (2000) Cranial nerve involvement in CMT disease type 1 due to early growth response 2 gene mutation. Neurology 54:1696-1698.

Parkinson DB, Bhaskaran A, Droggiti A, Dickinson S, D’Antonio M, Mirsky R, Jessen KR (2004) Krox-20 inhibits Jun-NH2-terminal kinase/c-Jun to control Schwann cell proliferation and death. J Cell Biol 164:385-394.

Parman Y, Battaloglu E, Baris I, Bilir B, Poyraz M, Bissar-Tadmouri N, Williams A, Ammar N, Nelis E, Timmerman V, De Jonghe P, Necefov A, Deymeer F, Serdaroglu P, Brophy PJ, Said G (2004) Clinicopathological and genetic study of early-onset demyelinating neuropathy. Brain 127:2540-2550.

Schneider-Maunoury S, Topilko P, Seitandou T, Levi G, Cohen-Tannoudji M, Pournin S, Babinet C, Charnay P (1993) Disruption of Krox-20 results in alteration of rhombomeres 3 and 5 in the developing hindbrain. Cell 75:1199-1214.

Seitanidou T, Schneider-Maunoury S, Desmarquet C, Wilkinson DG, Charnay P (1997) Krox-20 is a key regulator of rhombomere-specific gene expression in the developing hindbrain. Mech Dev 65:31-42.

Stoll G, Muller HW (1999) Nerve injury, axonal degeneration and neural regeneration: basic insights. Brain Pathol 9:313-325.

Swiatek PJ, Gridley T (1993) Perinatal lethality and defects in hindbrain development in mice homozygous for a targeted mutation of the zinc finger gene Krox20. Genes Dev 7:2071-2084.

Taillebourg E, Buart S, Charnay P (2002) Conditional, floxed allele of the Krox20 gene. Genesis 32:112-113.

Timmerman V, De Jonghe P, Ceuterick C, De Vriendt E, Lofgren A, Nelis E, Warner LE, Lupski JR, Martin JJ, Van Broeckhoven C (1999) Novel missense mutation in the early growth response 2 gene associated with Dejerine-Sottas syndrome phenotype. Neurology 52:1827-1832.

Topilko P, Schneider-Maunoury S, Levi G, Baron-Van Evercooren A, Chennoufi AB, Seitanidou T, Babinet C, Charnay P (1994) Krox-20 controls myelination in the peripheral nervous system. Nature 371:796-799.

Topilko P, Levi G, Merlo G, Mantero S, Desmarquet C, Mancardi G, Charnay $P$ (1997) Differential regulation of the zinc finger genes Krox-20 and Krox-24 (Egr-1) suggests antagonistic roles in Schwann cells. J Neurosci Res 50:702-712.

Vallat JM (2003) Dominantly inherited peripheral neuropathies. J Neuropathol Exp Neurol 62:699-714.

Vallat JM, Grid D, Magdelaine C, Sturtz F, Tazir M (2004) Autosomal recessive forms of Charcot-Marie-Tooth disease. Curr Neurol Neurosci Rep 4:413-419.

Voiculescu O, Charnay P, Schneider-Maunoury S (2000) Expression pattern of a Krox-20/Cre knock-in allele in the developing hindbrain, bones, and peripheral nervous system. Genesis 26:123-126.

Voiculescu O, Taillebourg E, Pujades C, Kress C, Buart S, Charnay P, Schneider-Maunoury S (2001) Hindbrain patterning: Krox20 couples segmentation and specification of regional identity. Development 128:4967-4978.

Vooijs M, Jonkers J, Berns A (2001) A highly efficient ligand-regulated Cre recombinase mouse line shows that LoxP recombination is position dependent. EMBO Rep 2:292-297.

Warner LE, Mancias P, Butler IJ, McDonald CM, Keppen L, Koob KG, Lupski JR (1998) Mutations in the early growth response 2 (EGR2) gene are associated with hereditary myelinopathies. Nat Genet 18:382-384.

Yoshihara T, Kanda F, Yamamoto M, Ishihara H, Misu K, Hattori N, Chihara $\mathrm{K}$, Sobue G (2001) A novel missense mutation in the early growth response 2 gene associated with late-onset Charcot-Marie-Tooth disease type 1. J Neurol Sci 184:149-153.

Zorick TS, Syroid DE, Arroyo E, Scherer SS, Lemke G (1996) The transcription factors SCIP and Krox-20 mark distinct stages and cell fates in Schwann cell differentiation. Mol Cell Neurosci 8:129-145. 